\title{
Habit Change of Monoclinic Hydroxyapatite Crystals Growing from Aqueous Solution in the Presence of Citrate Ions: The Role of 2D Epitaxy
}

\author{
Linda Pastero ${ }^{(\mathbb{})}$, Marco Bruno ${ }^{(\mathbb{1})}$ and Dino Aquilano * \\ Dipartimento di Scienze della Terra, Università degli Studi di Torino, Via Valperga Caluso 35, 10125 Torino, Italy; \\ linda.pastero@unito.it (L.P.); marco.bruno@unito.it (M.B.) \\ * Correspondence: dino.aquilano@unito.it; Tel.: +39-011-670-5125
}

Received: 9 July 2018; Accepted: 25 July 2018; Published: 27 July 2018

\begin{abstract}
Calcium hydroxyapatite (HAp) has been crystallized from aqueous solutions in the presence of citrate ions, in two temperature intervals. At lower temperature, where citrate could form the stable 3D-ordered phase Ca-citrate-tetrahydrate $(\mathrm{Ca}-\mathrm{Cit}-\mathrm{TH})$, only the monoclinic $\left(\mathrm{P} 2_{1} / \mathrm{c}\right) \mathrm{HAp}$ polymorph occurs and assumes the shape of fence-like aggregates, built by sharply [010] elongated lamellae dominated by the pinacoid $\{001\}$. This pronounced anisotropic growth habit is compared with the usually considered rod-like pseudo-hexagonal occurring in pure aqueous solution growth. The habit change is interpreted by assuming that 2D islands of Ca-citrate-tetrahydrate can be adsorbed as epimonolayers of thickness $d_{001}$ onto the different growth forms: $\{001\},\{100\},\{10 \overline{2}\},\{010\}$, and $\{10 \overline{1}\}$ of HAp. A comparison is made among the corresponding coincidence lattices, in order to explain on reticular basis the selective adsorption of citrate on the $\{001\}$ HAp form. The role exerted by the 2D-epitaxially adsorbed Ca-Cit-TH as a "mortar" in the monoclinic HAp "brick" assembly is outlined as well.
\end{abstract}

Keywords: hydroxyapatite; Ca-citrate; adsorption; 2D epitaxy; biomineralization

\section{Introduction}

The role of the citrate ion as an essential structural/functional component of bones is recognized since the forties [1]. The readers are kindly invited to consult an interesting and recent report on the historical evolution of this scientific topic dealing with the status of citrate in the hydroxyapatite/collagen complex of bone and its role in bone formation [2]. In this paper, we aim at focusing our attention to the more recent results on the action exerted by citrate ions on the calcium hydroxyapatite (HAp hereinafter) growing from solution. Specifically, we would like to deepen the mechanisms ruling the habit change of HAp, from the highly isotropic pseudo-hexagonal prismatic rod-like structure (in pure aqueous solutions) to the highly anisotropic flattened fence-like one (in citrate-doped solutions and in the bone of vertebrates). Results from simulation showed that citrate ions can bind strongly with Ca ions along the [001] axis on the $\{10 \overline{10}\}$ surfaces of the HAp crystal, supposed to be perfectly hexagonal, and are capable of regulating bone crystal growth by preferential adsorption in specific directions [3,4]. Citrate also stabilizes hydroxyapatite relative to other calcium phosphates [5], possibly due to the good match between the spacing of the terminal $\mathrm{COO}^{-}$groups in citrate and the lattice parameter $c$ in hexagonal-apatite. Furthermore, citrate bound to collagen initiates apatite crystallization in vitro [6]. Thus, citrate might play an important role not only in stabilizing existing apatite nanocrystals, but also in crystal nucleation during biomineralization in bone.

The strongly bound citrate in bone covers apatite at a density of about 1 molecule per $400 \AA^{2}$ (ca. 1/6 of the available surface area) and accounts for $5.5 \mathrm{wt} \%$ of the organic matter in bone [7]. 
The $\mathrm{CH}_{2}$ groups of citrate facing the exterior may give the surface a locally less hydrophilic character, making it more compatible with the nonpolar proline and alanine residues of the collagen matrix. In that research, apatite is represented as ideal hexagonal hydroxyapatite, $\mathrm{Ca}_{10}\left(\mathrm{PO}_{4}\right)_{6}(\mathrm{OH})_{2}$ $\left(a_{0}=b_{0}=9.44 \AA, c_{0}=6.88 \AA\right)$. As drawn in Figure 1, calcium ions in two planes of highest morphological importance [8] are shown on the top left and right. In the $(10 \overline{10})_{1}$ surface, $\mathrm{Ca}^{2+}$ is spaced by $c / 2=3.4 \AA$, which matches the $3.2 \AA$ spacing between the centres of the three $\mathrm{COO}^{-}$groups of citrate. In the $(10 \overline{10})_{2}$ surface, spacing of $c=6.88 \AA$ match the distance between the terminal carboxylates of citrate. The structure shown is an idealization of the calcium- and hydroxide-deficient carbonated bone apatite; the actual surface is probably reconstructed and significantly disordered.

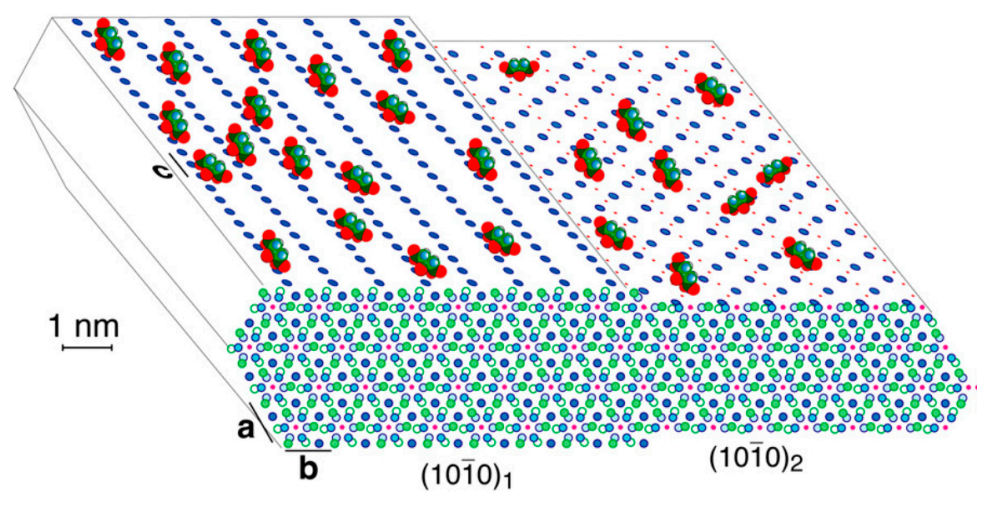

Figure 1. View along the [001] axis of the hexagonal HAp crystal structure. Scheme of apatite-bound citrate (with oxygen of the carboxylates in red) interacting with $\mathrm{Ca}^{2+}$ on two outmost terminations of the $\{10 \overline{1} 0\}$ surfaces, of an idealized bone apatite nanocrystal, at a citrate surface density of ca. $1 /(2 \mathrm{~nm})^{2}$. Calcium ions are blue filled circles on top and front surfaces, $\mathrm{P}$ is green (omitted on the top surfaces), $\mathrm{OH}^{-}$ions are pink dots, while phosphate oxygen is omitted for clarity. [7]. Figure reprinted with permission from: "Strongly bound citrate stabilizes the apatite nanocrystals in bone" by Hu, Y.Y.; Rawal, A.; Schmidt-Rohr, K. Proc. Natl. Acad. Sci. USA 2010, 107, 22425-22429. Copyright (C (2010), National Academy of Science.

The growth mechanism of biomimetic nanocrystalline apatites in the presence of citrate has been thoroughly characterized [9-12]. Following the proposed mechanism, citrate drives the growth pathway via an amorphous precursor stabilizing the amorphous calcium phosphate (ACP) at the early stage, controlling the amorphous $\rightarrow$ apatite transformation and the nanocrystal size by adsorption on the (1010) face. Then, citrate influences the growth of nanocrystals by a nonclassical oriented aggregation mechanism. The citrate molecules are too large to be incorporated into the cAp (citrate-carbonate-apatite) crystal lattice; therefore, it remains bound to the crystal surface, preferably in the $(10 \overline{1} 0)$ face and equivalent faces. This occurs because $\mathrm{Ca}^{2+}$ ions in the $(10 \overline{1} 0)$ face, at the two different surface profiles or sublevels, $(10 \overline{1} 0)_{1}$ and $(10 \overline{1} 0)_{2}$, are arranged with a spacing similar to the distance between the centres of the carboxylate groups in citrate, according to the way of thinking of Hu et al. [7].

Li et al. [13] demonstrated that citrate could effectively tune the sizes of Ca-P (calcium phosphate) primary particles/clusters during particle attachment on the hexagonal $\left(P 6_{3} / m\right)$ HAp $(10 \overline{1} 0)$ surface. Their AFM observations of spiral growth in the presence of citrate indicates that citrate stabilizes smaller Ca-P nanoclusters and modulates an oriented adsorption along the [001] direction. Nevertheless, one should outline that some incongruencies appear. As a matter of fact, even if the space group $P 6_{3} / \mathrm{m}$ is assumed, the spiral growth pattern on the lateral (1010) faces does not respect the symmetry plane $m$; this means that the investigated crystal cannot belong to the $P \sigma_{3} / m$ space group. Moreover, the growth pattern in the presence of $10 \mathrm{mM}$ citrate at $\mathrm{pH}=6$ shows a strong evolution from quasi-hexagonal to triangular. This pattern is totally asymmetric with respect to the plane perpendicular to the face and parallel to the [001] axis. 
Crystal orientation of hydroxyapatite along with the role exerted by citrate bridges and collagen between HAp platelets in bone have been carefully described as well [14-19].

From the whole of these researches, it follows that:

1. The interaction between the adsorbed citrate ions and the different faces of the HAp crystal is ruled, at best, by the fit between the lattice parameters of a given face and the distance between the centres of the carboxylate groups in citrate; this means that each citrate ion acts alone, without cooperating with other ions to make aggregates adsorbed on the growing crystal surfaces.

2. The adsorbed citrate ions are supposed to interact with a (1010) face of a HAp that is assumed to belong to a hexagonal space group. Accordingly, all the six symmetry-equivalent faces of the hexagonal prism could kinetically behave in the same way. Hence, the observed HAp habit change due to the action of citrate can be explained only by assuming that: (i) the space group of the HAp crystal growing in pure medium is originally monoclinic; and (ii) the action of citrate does not correspond to that of isolated entities (random adsorption) but to that of ordered 2D islands epitaxially adsorbed onto the different crystallographic surfaces of all the most important HAp forms.

Then, we will move along these just mentioned directions in interpreting the experimental results exposed in the following section.

\section{Materials and Methods}

Monetite, as the hydroxyapatite precursor, was obtained as described in our previous papers [20,21]. Ultrapure water $18 \mathrm{M} \Omega$ was obtained using an Elga Purelab Flex3 (Veolia Elga LabWater, High Wycombe, UK) system. Analytical-grade citric acid was purchased from Sigma-Aldrich (Sigma-Aldrich, St Louis, MO, USA). Experimental runs were carried out to confirm the effect of the citrate on the growth morphology of apatite found in the literature. Moreover, we aimed to distinguish the effect of the supersaturation from that of the citrate as a specific surface impurity: in fact, we know that at high supersaturation with respect to HAp, crystals grow with a ribbon-like morphology that could be mistaken for that usually obtained in the presence of citrate [21,22]. To reach our goals, it was essential to obtain large crystals useful for the morphological study. Low-temperature experiments lead to the growth of nanosized HAp crystals [21], so we moved to low hydrothermal conditions in order to increase the size and the quality of the crystals obtained.

The first experiments have been performed working under mild hydrothermal conditions, following the same procedure as described in Pastero et al. [21]. Four millilitres of $0.1 \mathrm{M}$ citric acid were added to the monetite/water suspension. The amount of citric acid was chosen in order to lower the $\mathrm{pH}$ of the suspension to reach a value comparable to what we verified as being the optimal value $(\mathrm{pH} \approx 3)$ to grow large crystals in the pure system [21]. Furthermore, citric acid was chosen instead of calcium citrate in order to keep constant the $\mathrm{Ca}^{2+} / \mathrm{PO}_{4}{ }^{3-}$ ratio with respect to reference experiments. Calcium citrate enters the system due to the speciation during the hydrolysis reaction. The early experiments were performed at low hydrothermal conditions $\left(210^{\circ} \mathrm{C}\right.$ and autogenic pressure) for long times of reaction (15 days). From these experiments, we obtained very large (sometimes up to $1 \mathrm{~cm}$ long) prismatic crystals optically yellowish (Figure 2a,b). The behaviour of these crystals is explained by the thermal decomposition of the citric acid, which starts slowly at $148^{\circ} \mathrm{C}$, while the rate of reaction increases from the melting point $\left(153 \pm 0.1^{\circ} \mathrm{C}\right)$, reaches a maximum at $188^{\circ} \mathrm{C}$, and finally decreases above $212^{\circ} \mathrm{C}$ [23].

Having taken into account the thermal behavior of citric acid, we cannot modify the original monetite hydrolysis experiments only by adding citric acid; instead, the reaction temperature must be lowered. Hence, new experiments were performed by keeping the chemical composition of the starting suspension but lowering the temperature to $135^{\circ} \mathrm{C}$ (Figure $2 \mathrm{c}, \mathrm{d}$ ) and $40{ }^{\circ} \mathrm{C}$, keeping the system sealed for 15 days. Experiments performed at $40^{\circ} \mathrm{C}$ were not successful: we compared a test experiment in pure conditions to a series of runs prepared in the presence of citric acid. In test 
experiments, the reaction of hydrolysis of the monetite was not efficient at low temperature, while from acidified suspensions, HAp crystals did not precipitate. Nevertheless, we can consider the experiments performed at $135^{\circ} \mathrm{C}$ as representative of the effect of the citrate on the crystal growth of the HAp because of the equivalence of the chemical conditions: in this case, the temperature acts as a booster for the growth rates of the stable crystal forms.

From $135{ }^{\circ} \mathrm{C}$ runs, we obtained flat, tabular HAp crystals, confirming the data about the morphological effect of citrate on the growth morphology of HAp found in the literature. Moreover, HAp crystals so obtained show recurrent parallel growth, forming fence-like aggregates.

The crystals obtained from each growth run were analyzed by X-ray powder diffraction using a Siemens D5000 diffractometer (Siemens, Munich, Germany) (Bragg-Brentano geometry, $2.5^{\circ}<2 \theta<100^{\circ}$, step size 0.01 , scan time $2.5 \mathrm{~s} / \mathrm{step}$ ), confirming that no foreign crystalline phases are obtained under the experimental conditions.
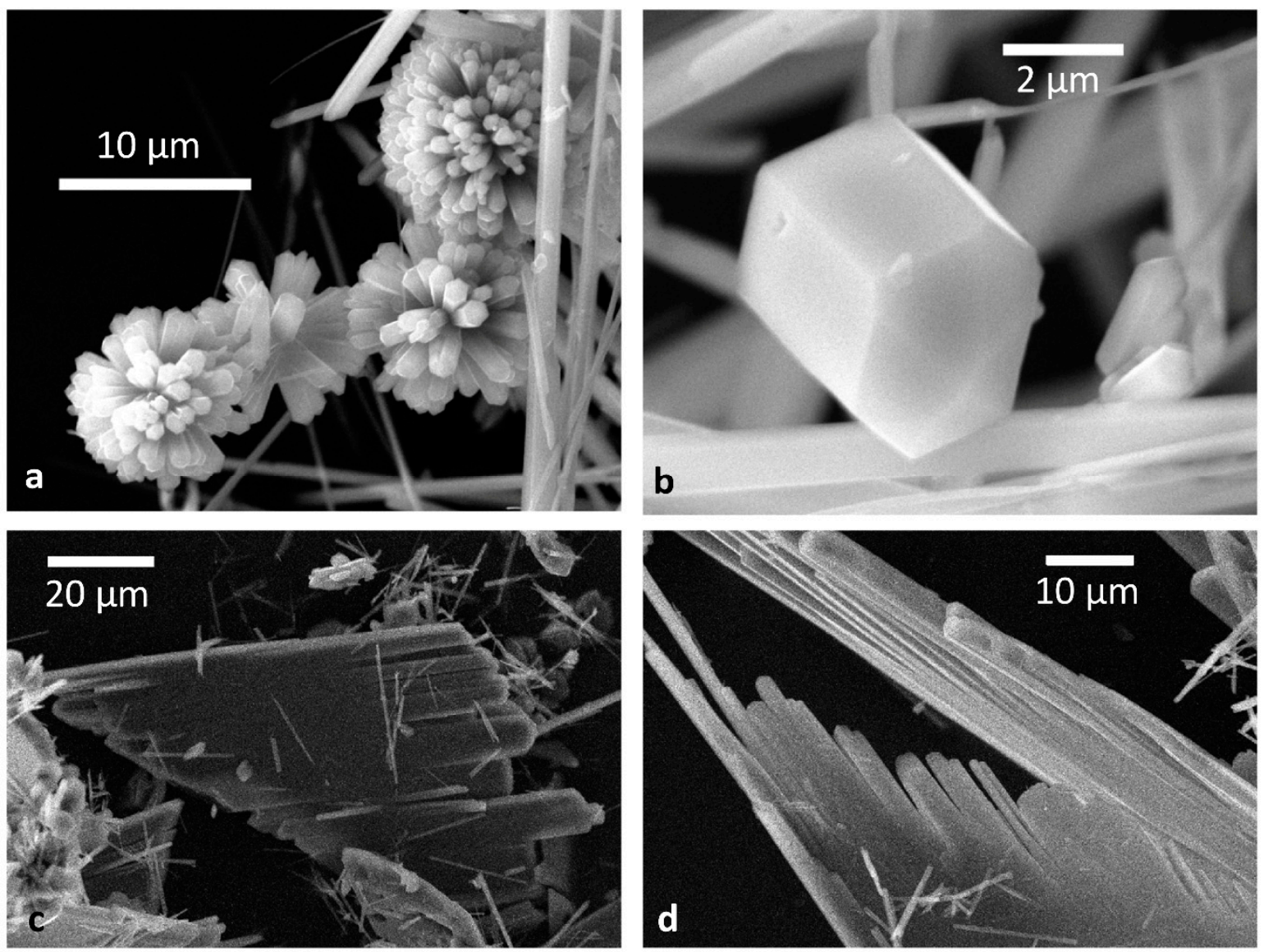

Figure 2. (a,b) Hydroxyapatite grown from a monetite/water suspension at $210{ }^{\circ} \mathrm{C}$ and autogenic pressure in the presence of citric acid; (c,d) hydroxyapatite grown from the same suspension as in $(\mathbf{a}, \mathbf{b})$, but at $135^{\circ} \mathrm{C}$. It is worth outlining that the lengths of the individuals building the fence-like aggregate progressively decrease, indicating different nucleation times during the growth stacking.

To fulfil the epitaxial conditions between the host (HAp) and the guest (Ca-Cit-TH) phases, a common interface is required: a common 2D super-lattice must be generated from the superposition of the lattice planes belonging to host and guest. From the points making this 2D superlattice, a 2D- coincidence lattice cell is obtained, as illustrated in detail in S.I. (Figures SI1-SI3). To do that, we compared the surface cells of the Ca-Cit-TH $\{001\}$ form, with the HAp surface cells of the $\{001\}$, $\{\overline{1} 02\},\{010\}$, and $\{10 \overline{1}\}$ forms. 


\section{Results and Discussion}

Starting from the sharply different crystal morphologies we obtained at different crystallization temperatures, we were induced to put forward the hypothesis that the HAp habit modifications observed at lower temperature could be attributed to the action of selective adsorption of a 2D-ordered phase built by hydrated $\mathrm{Ca}^{2+}$ and citrate ions. The alternative and usual hypothesis grounded on the adsorption of the isolated citrate ions can hardly work, for two independent reasons: first, because isolated impurities can only affect the advancement rate of growth steps (for both spirals and/or 2D nuclei) and, second, because isolated impurities could be adsorbed at the same coverage degree onto the six equivalent HAp prismatic faces, as it has been usually assumed when the breaking of the hexagonal symmetry is invoked. Thus, isolated citrate ions cannot change the pseudo-hexagonal prismatic HAp shape (as occurs in pure aqueous solutions) to the extremely fence-like aggregates (as observed in the presence of citrate either in lab, at $135^{\circ} \mathrm{C}$, or in nature, at physiological temperature).

The path we will follow to explain this dramatic morphological change is based on two starting assumptions, as just mentioned in the Introduction:

- The Ca-HAp polymorph crystallizing in aqueous solutions at room temperature is monoclinic

- The citrate ions are adsorbed as ordered 2D-islands built by the sole stable phase of Ca-citrate-hydrate, at room temperature, that is, the Ca-Cit-TH (tri-Calcium di-Citrate tetra-Hydrate). This Ca-citrate phase has been recently pointed out as a new relevant biomaterial for bone formation [24].

Thus, we aim at searching for potential epitaxies between the most important faces of HAp (host) and Ca-Cit-TH (guest), as it was successfully done in preceding researches [21,25-30].

Concerning the monoclinic polymorph of the Ca-HAp, we adopted the optimized conventional cell: $a_{0}=9.3253 ; b_{0}=6.9503 ; c_{0}=18.6436$ (in $\AA$ ) $; \beta=119.972^{\circ}$, referred to the space group $P 2{ }_{1} / c$ and to 4 unit formulas (i.e., $\left.\mathrm{Ca}_{20}(\mathrm{OH})_{4}\left(\mathrm{PO}_{4}\right)_{12}\right)$. The setting $P 2_{1} / c$ has been preferred to $P 2_{1} / b$ only because the screw diad axis $\left(2_{1}\right)$ traditionally coincides, in the monoclinic system, with the y axis. The extinction rules are: h0l: $1=2 n ; 0 k 0: k=2 n ; 001: 1=2 n$. The most important forms limiting the relaxed equilibrium shape (E.S.) of the crystal, as calculated at $0 \mathrm{~K}$, are the three pinacoids, $\{100\},\{001\}$, and $\{10 \overline{2}\}$, that, all together, simulate the shape of a pseudo-hexagonal prism developing along the diad axis and parallel the $\mathrm{OH}^{-}$channels; the fourth important form is the $\{010\}$ pinacoid, orthogonal to the prism axis. All these pinacoids have flat (F) character [31]. Another form exists, which does not belong to the theoretical growth shape (G.S.) of the crystal: the pinacoid $\{10 \overline{1}\}$, whose corresponding thickness $\mathrm{d}_{10-1}$ doesn't fulfil the just mentioned extinction rules of the space group $P 2_{1} / c$. For this reason, and also because it does not occur in growth from pure aqueous solution, it has not yet been considered in literature. Nevertheless, we will deal with it, owing to the role it plays when HAp crystals grow in the presence of citrate ions.

For Ca-Cit-TH $\left(\left[\mathrm{Ca}_{3}\left(\mathrm{C}_{6} \mathrm{H}_{5} \mathrm{O}_{7}\right)_{2}\left(\mathrm{H}_{2} \mathrm{O}\right)_{2}\right] \cdot 2 \mathrm{H}_{2} \mathrm{O}\right)$, the triclinic $(P \overline{1})$ cell determined by Herdtweck et al. [32] has been chosen: $a_{0}=5.9466 ; b_{0}=10.2247 ; c_{0}=16.6496$ (in $\AA$ ); $\alpha=72.213^{\circ}$, $\beta=79.718^{\circ}, \gamma=89.79^{\circ}$. The three-dimensional network is built up by strings of $\mathrm{Ca}_{1}$ double polyhedra oriented along the $a$-axis and rippled planes of $\mathrm{Ca}_{2}$ and $\mathrm{Ca}_{3}$ double polyhedra parallel to the $a_{0} b_{0}$-plane. This means that the crystal shape does show a well-developed $\{001\}$ form, due to its layered structure.

In this paper, we will confine our attention to the geometrical constraints that could be necessary to fulfil for the epitaxy to occur, that is, the lower the area of the 2D-coincidence lattice that forms at the interface between A (host) and B (guest), the higher the probability of finding the corresponding A/B epitaxy. This simple rule is not only valid for epitaxies but also for every couple of differently oriented lattices generating a common interface, as it was proven since the seventies for A/A interfaces of the growth twins, periodic polysynthetic twins, and polytypes [33-35]. The evaluation of the adhesion energies corresponding to the just mentioned coincidence lattices represents the successive step needed to build a more quantitative epitaxy ranking, but the energy calculation about the couple 
HAp/Ca-Cit-TH does carry out a heavy work, which is beyond the limits of this paper and will be the subject of a forthcoming research.

From Tables 1-4, one can see that the ranking of the 2D-coincidence lattice areas of the HAp forms coupled with the $\{001\}$ form of Ca-Cit-TH carries out unambiguous consequences. In detail:

1. the $\{001\}_{\text {HAp }}$ form shows 6 coincidence lattices, 5 of them having their multiplicity ranging between an absolute minimum $(5 \times)$ and a moderate maximum $(8 \times)$ with respect to the area of the $\{001\}_{\text {Ca-Cit-TH }} 2 \mathrm{D}$-unit cell;

2. for the $\{\overline{1} 01\}_{\text {HAp }}$ form, 6 coincidence lattices can be found as well, but only 2 of them do fulfil the just mentioned multiplicity criterion, their multiplicities being $(7 \times)$;

3. concerning the two pinacoids $\{100\}_{\text {HAp }}$ and $\{\overline{1} 02\}_{\text {HAp }}, 3$ coincidence lattices are found, but only one of them shows a good multiplicity $(6 \times)$, the other two being $(10 \times)$ and $(13 \times)$;

4. the $\{010\}_{\mathrm{HAp}}$ form, which is orthogonal to the $\mathrm{OH}^{-}$channels in HAp crystals, shows 10 coincidence lattices, only one of them having a reasonable multiplicity $(7 \times)$ for a 2D epitaxy to occur.

Table 1. 2D-coincidence lattices between the $\{001\}$ form of HAp and the $\{001\}$ form of Ca-Cit-TH. Rotation angle refers to the angle formed between the vectors [100] of both the involved 2D cells.

\begin{tabular}{|c|c|c|c|c|c|}
\hline $\begin{array}{c}\text { Features of the } \\
\text { 2D-Coincidence Cell }\end{array}$ & Ranking & $\begin{array}{c}\text { HAp }\{001\} \text { Area } \\
64.81 \AA^{2}\end{array}$ & $\begin{array}{c}\text { Ca-Cit-TH }\{001\} \\
\text { Area } 60.80 \AA^{2}\end{array}$ & $\begin{array}{l}\text { Misfit } \\
(\%)\end{array}$ & $\begin{array}{l}\text { Rotation } \\
\left.\text { Angle ( }{ }^{\circ}\right)\end{array}$ \\
\hline 2D-lattice parameters $(\AA)$ & & $\begin{array}{c}{[1 \overline{1} 0]=11.631} \\
5 \times[100]=46.626\end{array}$ & $\begin{array}{l}{[1 \overline{1} 0]=11.848} \\
{[7 \overline{2} 0]=46.397}\end{array}$ & $\begin{array}{l}+1.86 \\
-0.49\end{array}$ & 25 \\
\hline \multirow[t]{15}{*}{$\begin{array}{l}\text { Area }\left(\AA^{2}\right) \text { and multiplicity } \\
\text { of the } 2 \mathrm{D} \text {-coincidence cell }\end{array}$} & 1st & $324.068(5 \times)$ & $304.011(5 \times)$ & -6.6 & \\
\hline & & $\begin{array}{l}2 \times[100]=18.651 \\
3 \times[010]=20.851\end{array}$ & $\begin{array}{l}3 \times[100]=17.840 \\
2 \times[010]=20.449\end{array}$ & $\begin{array}{l}-4.54 \\
-1.74\end{array}$ & 0 \\
\hline & 2nd & $388.882(6 \times)$ & $364.813(6 \times)$ & -6.6 & \\
\hline & & {$[320]=31.239$} & {$[510]=31.442$} & +0.65 & 8 \\
\hline & & {$[2 \overline{1} 0]=19.903$} & {$[3 \overline{1} 0]=20.562$} & +3.31 & \\
\hline & 3rd (a) & $453.695(7 \times)$ & $486.417(8 \times)$ & +6.72 & \\
\hline & & $2 \times[1 \overline{2} 0]=33.477$ & {$[2 \overline{3} 0]=32.899$} & -1.76 & 13 \\
\hline & & {$[3 \overline{2} 0]=31.239$} & $2 \times[2 \overline{1} 0]=30.026$ & -4.04 & \\
\hline & 3rd (b) & $518.509(8 \times)$ & $486.417(8 \times)$ & -6.6 & \\
\hline & & {$[2 \overline{1} 0]=19.903$} & $-[020]=20.449$ & +2.74 & 67 \\
\hline & & {$[320]=31.239$} & $2 \times[2 \overline{1} 0]=30.026$ & -4.04 & \\
\hline & 3rd (c) & $453.695(7 \times)$ & $486.417(8 \times)$ & +6.72 & \\
\hline & & $4 \times[100]=37.301$ & {$[6 \overline{1} 0]=37.122$} & -0.48 & 16 \\
\hline & & $3 \times[010]=20.851$ & {$[120]=21.339$} & +2.34 & \\
\hline & 4th & $777.764(12 \times)$ & $790.43(13 \times)$ & +1.63 & \\
\hline
\end{tabular}


Table 2. 2D-coincidence lattices between the $\{100\}$ and $\{102\}$ forms of HAp and the $\{001\}$ form of Ca-Cit-TH. Owing to the practical equality between the $\{100\}$ and $\{\overline{1} 02\}-2 \mathrm{D}$ surface lattices, only the coincidences of the $\{\overline{1} 02\}$ form have been illustrated. Rotation angle refers to the angle formed between the vectors [100] of both the involved 2D cells.

\begin{tabular}{|c|c|c|c|c|c|}
\hline $\begin{array}{c}\text { Features of the } \\
\text { 2D-Coincidence Cell }\end{array}$ & Ranking & $\begin{array}{c}\text { HAp }\{\overline{102}\} \text { Area } \\
129.66 \AA^{2}\end{array}$ & $\begin{array}{c}\text { Ca-Cit-TH }\{001\} \\
\text { Area } 60.80 \AA^{2}\end{array}$ & $\begin{array}{c}\text { Misfit } \\
(\%)\end{array}$ & $\begin{array}{l}\text { Rotation } \\
\text { Angle }\left({ }^{\circ}\right)\end{array}$ \\
\hline 2D-lattice parameters $(\AA)$ & & $\begin{array}{c}{[201]=18.655} \\
3 \times[010]=20.851\end{array}$ & $\begin{array}{l}3 \times[100]=17.839 \\
2 \times[010]=20.449\end{array}$ & $\begin{array}{l}-4.57 \\
-1.745\end{array}$ & 0 \\
\hline \multirow[t]{5}{*}{$\begin{array}{l}\text { Area }\left(\AA^{2}\right) \text { and multiplicity } \\
\text { of the 2D-coincidence cell }\end{array}$} & 1 st & $388.973(3 \times)$ & $3.813(6 \times)$ & -6.6 & \\
\hline & & $\begin{array}{c}{[412]=38.542} \\
-[221]=23.264\end{array}$ & $\begin{array}{l}{[6 \overline{1} 0]=37.116} \\
{[\overline{2} 20]=23.656}\end{array}$ & $\begin{array}{l}-3.82 \\
+1.85 \\
\end{array}$ & 25 \\
\hline & 2nd & $648.289(5 \times)$ & $608.022(10 \times)$ & -6.62 & \\
\hline & & $\begin{array}{l}2 \times[201]=37.310 \\
3 \times[010]=20.851\end{array}$ & $\begin{array}{l}{[6 \overline{1} 0]=37.116} \\
{[120]=21.339}\end{array}$ & $\begin{array}{l}-0.506 \\
+2.34\end{array}$ & 17 \\
\hline & $3 \mathrm{rd}$ & $777.946(6 \times)$ & $790.43(13 \times)$ & +1.60 & \\
\hline
\end{tabular}

Table 3. 2D-coincidence lattices between the $\{010\}-H A p$ form and the $\{001\}$ form of Ca-Cit-TH. Rotation angle refers to the angle formed between the vectors [100] of both the involved 2D cells.

\begin{tabular}{|c|c|c|c|c|c|}
\hline $\begin{array}{c}\text { Features of the } \\
\text { 2D-Coincidence Cell }\end{array}$ & Ranking & $\begin{array}{c}\text { HAp }\{010\} \text { Area } \\
150.60 \AA^{2}\end{array}$ & $\begin{array}{l}\text { Ca-Cit-TH }\{001\} \\
\text { Area } 60.80 \AA^{2}\end{array}$ & $\begin{array}{l}\text { Misfit } \\
(\%)\end{array}$ & $\begin{array}{l}\text { Rotation } \\
\text { Angle }\left(^{\circ}\right)\end{array}$ \\
\hline 2D-lattice parameters ( $\mathrm{A})$ & & $\begin{array}{c}-[101]=16.150 \\
3 \times[100]=27.975\end{array}$ & $\begin{array}{c}-[210]=15.648 \\
{[3 \overline{2} 0]=27.137}\end{array}$ & $\begin{array}{l}-2.97 \\
-3.09\end{array}$ & 47 \\
\hline \multirow[t]{21}{*}{$\begin{array}{l}\text { Area }\left(\AA^{2}\right) \text { and multiplicity } \\
\text { of the } 2 \mathrm{D} \text {-coincidence cell }\end{array}$} & 1st & $451.816(3 \times)$ & $425.611(7 \times)$ & -6.6 & \\
\hline & & $\begin{array}{l}2 \times[100]=18.650 \\
-2 \times[101]=32.301\end{array}$ & $\begin{array}{c}3 \times[100]=17.84 \\
3 \times[010]=30.673\end{array}$ & $\begin{array}{l}-4.54 \\
-5.30\end{array}$ & 0 \\
\hline & 2nd & $602.422(4 \times)$ & $547.215(9 \times)$ & -10.09 & \\
\hline & & $\begin{array}{l}4 \times[100]=37.301 \\
3 \times[301]=24.680\end{array}$ & $\begin{array}{l}{[6 \overline{1} 0]=37.122} \\
-[410]=25.891\end{array}$ & $\begin{array}{l}-0.48 \\
+4.90\end{array}$ & 17 \\
\hline & 3rd (a) & $602.4222(4 \times)$ & $608.016(10 \times)$ & -0.93 & \\
\hline & & $\begin{array}{c}4 \times[100]=37.301 \\
{[101]=16.1503}\end{array}$ & $\begin{array}{l}{[4 \overline{3} 0]=38.816} \\
{[210]=15.684}\end{array}$ & $\begin{array}{l}+4.06 \\
-2.97\end{array}$ & 53 \\
\hline & 3rd (b) & $602.4222(4 \times)$ & $608.016(10 \times)$ & -0.93 & \\
\hline & & $\begin{array}{c}5 \times[100]=46.626 \\
{[20 \overline{1}]=32.293}\end{array}$ & $\begin{array}{l}{[6 \overline{3} 0]=47.052} \\
{[2 \overline{3} 0]=32.898}\end{array}$ & $\begin{array}{l}+0.91 \\
+1.87\end{array}$ & 41 \\
\hline & 4th (a) & $753.025(5 \times)$ & $729.619(12 \times)$ & -3.21 & \\
\hline & & $\begin{array}{l}{[30 \overline{1}]=40.638} \\
{[201]=18.655}\end{array}$ & $\begin{array}{c}{[1 \overline{4} 0]=41.328} \\
3 \times[100]=17.84\end{array}$ & $\begin{array}{l}+1.70 \\
-4.56\end{array}$ & 59 \\
\hline & 4th (b) & $753.025(5 \times)$ & $729.619(12 \times)$ & -3.21 & \\
\hline & & $\begin{array}{l}{[401]=32.313} \\
{[202]=32.301}\end{array}$ & $\begin{array}{l}{[510]=31.442} \\
{[130]=31.244}\end{array}$ & $\begin{array}{l}-2.77 \\
-3.38\end{array}$ & 11 \\
\hline & 5 th & $903.633(6 \times)$ & $851.22(14 \times)$ & -6.16 & \\
\hline & & $\begin{array}{l}{[30 \overline{1}]=40.638} \\
{[302]=33.626}\end{array}$ & $\begin{array}{l}{[6 \overline{2} 0]=41.124} \\
{[230]=32.898}\end{array}$ & $\begin{array}{l}+1.19 \\
-2.21\end{array}$ & 7 \\
\hline & 6th (a) & $1355.445(9 \times)$ & $1337.63(22 \times)$ & -1.33 & \\
\hline & & $\begin{array}{c}-[102]=33.613 \\
{[40 \overline{1}]=49.333}\end{array}$ & $\begin{array}{c}-[230]=32.898 \\
{[5 \overline{4} 0]=50.564}\end{array}$ & $\begin{array}{l}-2.17 \\
+2.49\end{array}$ & 35 \\
\hline & 6th (b) & $1355.445(9 \times)$ & $1398.44(23 \times)$ & +3.17 & \\
\hline & & $\begin{array}{c}{[10 \overline{2}]=42.716} \\
2 \times[201]=37.310\end{array}$ & $\begin{array}{c}2 \times[1 \overline{2} 0]=42.592 \\
{[520]=36.086}\end{array}$ & $\begin{array}{l}-0.25 \\
-3.39\end{array}$ & 25 \\
\hline & 7th (a) & $(10 \times) 1506.05$ & $(24 \times) 1459.24$ & -3.21 & \\
\hline & & $\begin{array}{c}{[30 \overline{1}]=40.638} \\
2 \times[201]=37.310\end{array}$ & $\begin{array}{c}-[140]=41.328 \\
{[6 \overline{1} 0]=37.122}\end{array}$ & $\begin{array}{l}+1.70 \\
-0.51 \\
\end{array}$ & 76 \\
\hline & 7th (b) & $(10 \times) 1506.05$ & $(25 \times) 1520.04$ & +0.93 & \\
\hline
\end{tabular}


Table 4. 2D-coincidence lattices between the $\{10 \overline{1}\}$-HAp form and the $\{001\}$ form of Ca-Cit-TH. Rotation angle refers to the angle formed between the vectors [010] $]_{\mathrm{HAp}}$ and the vector $[100]_{\mathrm{Ca}-\mathrm{Cit}-\mathrm{TH}}$.

\begin{tabular}{|c|c|c|c|c|c|}
\hline $\begin{array}{c}\text { Features of the } \\
\text { 2D-Coincidence Cell }\end{array}$ & Ranking & $\begin{array}{c}\text { HAp }\{10 \overline{1}\} \text { Area } \\
113.445 \AA^{2}\end{array}$ & $\begin{array}{l}\text { Ca-Cit-TH }\{001\} \\
\text { Area } 60.80 \AA^{2}\end{array}$ & $\begin{array}{l}\text { Misfit } \\
(\%)\end{array}$ & $\begin{array}{l}\text { Rotation } \\
\text { Angle }\left(^{\circ}\right)\end{array}$ \\
\hline 2D-lattice parameters $(\AA)$ & & $\begin{array}{c}{[101]=16.322} \\
4 \times[010]=27.801\end{array}$ & $\begin{array}{l}{[2 \overline{1} 0]=15.684} \\
{[320]=27.137}\end{array}$ & $\begin{array}{l}-4.07 \\
-2.44\end{array}$ & 41.5 \\
\hline \multirow[t]{15}{*}{$\begin{array}{l}\text { Area }\left(\AA^{2}\right) \text { and multiplicity } \\
\text { of the } 2 \mathrm{D} \text {-coincidence cell }\end{array}$} & 1st (a) & $453.782(4 \times)$ & $425.615(7 \times)$ & -6.61 & \\
\hline & & $\begin{array}{c}2 \times[101]=32.645 \\
{[121]=21.44}\end{array}$ & $\begin{array}{l}{[2 \overline{3} 0]=32.899} \\
{[3 \overline{1} 0]=20.562}\end{array}$ & $\begin{array}{l}+0.78 \\
-4.27\end{array}$ & \\
\hline & 1st (b) & $453.782(4 \times)$ & $425.615(7 \times)$ & -6.61 & 70 \\
\hline & & $\begin{array}{c}{[2 \overline{1} 2]=33.376} \\
2 \times[111]=35.48\end{array}$ & $\begin{array}{l}{[2 \overline{3} 0]=32.899} \\
{[5 \overline{2} 0]=36.086}\end{array}$ & $\begin{array}{l}-1.45 \\
+1.71\end{array}$ & \\
\hline & 2nd (a) & $680.67(6 \times)$ & $668.82(11 \times)$ & -1.77 & 57 \\
\hline & & $\begin{array}{c}2 \times[1 \overline{1} 1]=35.48 \\
{[121]=21.44}\end{array}$ & $\begin{array}{l}{[5 \overline{2} 0]=36.086} \\
{[310]=20.562}\end{array}$ & $\begin{array}{l}+1.71 \\
-4.27\end{array}$ & \\
\hline & 2nd (b) & $680.67(6 \times)$ & $668.82(11 \times)$ & -1.77 & 10 \\
\hline & & $\begin{array}{l}2 \times[101]=32.645 \\
3 \times[010]=20.851\end{array}$ & $\begin{array}{l}{[5 \overline{1} 0]=31.442} \\
{[120]=21.296}\end{array}$ & $\begin{array}{r}-3.82 \\
+2.137 \\
\end{array}$ & \\
\hline & 2nd (c) & $680.67(6 \times)$ & $668.82(11 \times)$ & -1.77 & 20 \\
\hline & & $\begin{array}{c}{[151]=8.394} \\
-[1 \overline{2} 1]=21.44\end{array}$ & $\begin{array}{c}{[610]=37.116} \\
2 \times[010]=20.45\end{array}$ & $\begin{array}{l}-3.44 \\
-4.84\end{array}$ & \\
\hline & $3 \mathrm{rd}$ & $793.25(7 \times)$ & $729.622(12 \times)$ & -8.72 & 50 \\
\hline & & $\begin{array}{l}{[212]=33.376} \\
{[151]=38.394}\end{array}$ & $\begin{array}{l}{[2 \overline{3} 0]=32.899} \\
{[6 \overline{1} 0]=37.116}\end{array}$ & $\begin{array}{l}-1.45 \\
-3.44\end{array}$ & \\
\hline & 4 th & $1019.90(9 \times)$ & $972.83(16 \times)$ & -4.83 & 82 \\
\hline & & $\begin{array}{c}2 \times[1 \overline{2} 1]=42.88 \\
{[131]=26.48}\end{array}$ & $\begin{array}{l}{[5 \overline{3} 0]=42.767} \\
{[320]=27.137}\end{array}$ & $\begin{array}{l}-0.076 \\
+2.48\end{array}$ & \\
\hline & 5 th & $1134.45(10 \times)$ & $1155.24(19 \times)$ & +1.83 & 5 \\
\hline
\end{tabular}

When summarizing, the coupling $\{001\}_{\mathrm{HAp}} /\{001\}_{\mathrm{Ca}-\mathrm{Cit}-\mathrm{TH}}$ is the most favourable for the nucleation, onto the growing HAp surfaces, of Ca-citrate 2D-islands that, competing with the Ca-phosphate growth units coming from solution, do hinder the growth kinetics of the affected faces. Moreover, it is worth remembering that the $\{001\}_{\mathrm{HAp}}$ pinacoid shows the most anisotropic surfaces in the [010]-HAp zone, being the only one (at variance with the $\{100\}$ and $\{10 \overline{2}\}$ pinacoids) in which the $\mathrm{OH}^{-}$groups alternate up/down within the successive $\mathrm{d}_{002}$ slices [31]; this further increases the adhesion probability between the growing $\{001\}_{\mathrm{HAp}}$ surfaces and the centrosymmetric adsorbing $\{001\}_{\mathrm{Ca}-\mathrm{Cit}-\mathrm{TH}}$ layers.

This is the main reason why the pseudo-hexagonal prismatic symmetry of the HAp growing in pure aqueous solution reduces to the $\{001\}$-flattened growth shape, so outlining once more its original monoclinic symmetry; in other words, the rate of growth of $\{001\}_{\mathrm{HAp}}$ form is lowered by Ca-citrate epi-adsorption which should be significantly less effective on the four faces defining the $\{100\}$ and $\{10 \overline{2}\}$ pinacoids (Figure 3).

A novelty due to the Ca-citrate action is represented by the stabilization of the pinacoid $\{10 \overline{1}\}_{\text {HAp }}$. This form had never been considered before, owing to its stepped character, but we will deal with its morphological importance (both at equilibrium and during growth), in a forthcoming paper.

From item (2), it comes out that the effectiveness of the Ca-citrate epi-adsorption results were intermediate between that affecting the $\{001\}$ (the maximum) and the couple of $\{100\}$ and $\{10 \overline{2}\}$ forms (the minimum). Hence, one can argue that a monolayer $\mathrm{d}_{001}$ of Ca-citrate could stabilize and flatten the $\{10 \overline{1}\}_{\text {HAp }}$ surface, changing its character from stepped to flat; in turn, this (or more) Ca-citrate 
monolayer could work as a sandwich between two (or more) contiguous [010] elongated and flat single HAp crystals, according to the mechanism proposed in Figure 3, bottom. Thus, a genetic algorithm, analogous to the "brick and mortar" way operating in the building of the mollusk shells, could explain two aspects of the HAp/citrate interaction:

1. The crystallographic allowance of the two involved 3D structures that originates the epitaxial relationships gives rise to the dramatic modifications of the HAp habit; it is worth outlining as well that the sandwiched Ca-citrate layers are centre-symmetric and, consequently, no constraints are imposed to the nucleation of a new HAp individual on a $\{10 \overline{1}\}_{\text {HAp }}$ crystal face which should work as a substrate. Moreover, when carefully looking at Figure $2 b$, it comes out that another kind of fence-like aggregate can form, made by stacked HAp single crystals all elongated along the [010] direction and "welded" together through their $\{001\}$ faces. Having considered that $\{001\}_{\text {Ca-Cit-TH }}$ layers can be easily adsorbed onto the $\{001\}_{\text {HAp }}$ faces, one could accept also in this case the hypothesis that these layers can be sandwiched in between two successive adjacent single and iso-oriented HAp crystals.

2. The few Ca-citrate layers favouring the formation of the flattened and fence-like HAp morphology assume the function of the "mortar" cementing the apatitic crystal, in the same way as the 2D-sericin ordered layers work in between aragonite and calcite crystals in assembling the mollusk shells [36].

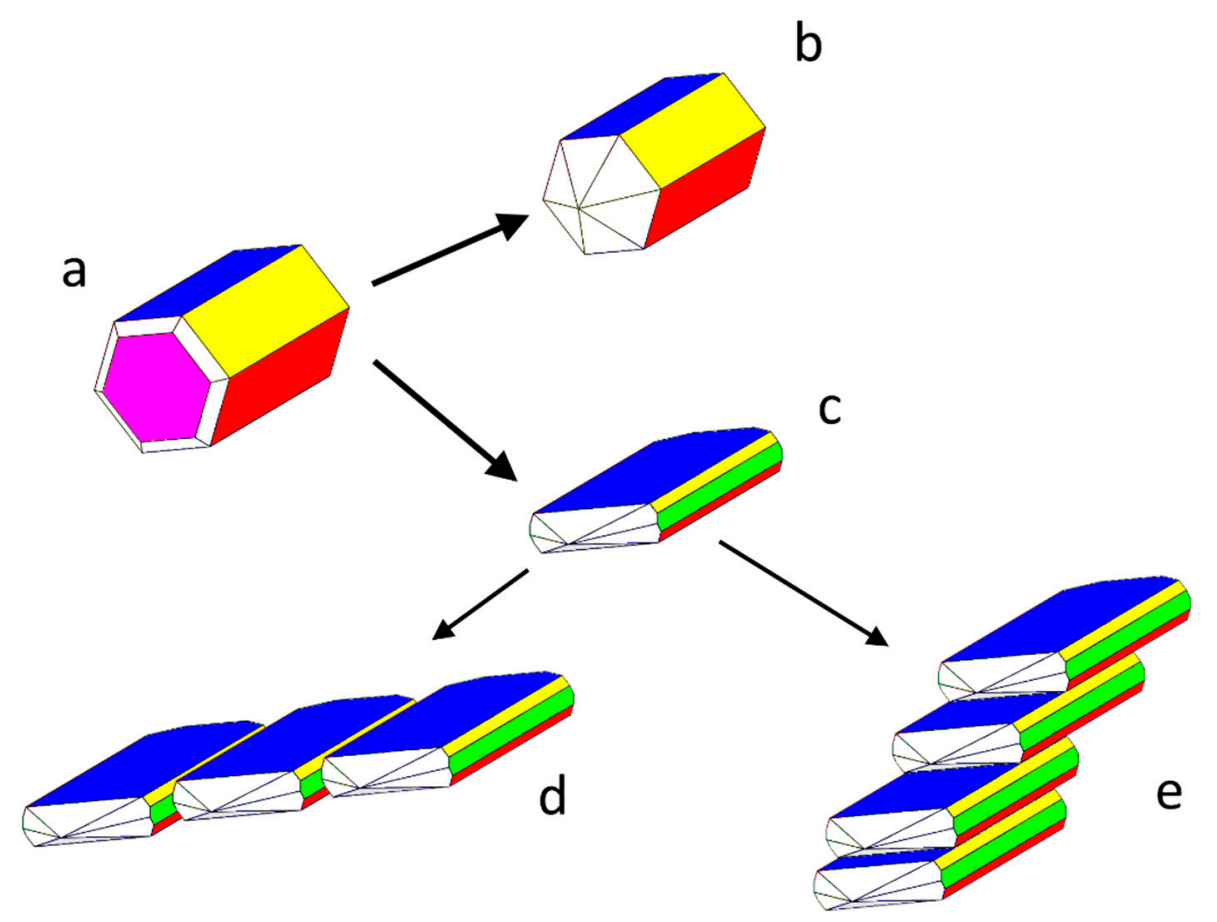

Figure 3. (a) Calculated equilibrium shape of the monoclinic HAp crystal: the pseudo-hexagonal prismatic shape is built up by the pinacoids $\{001\}$-blue, $\{100\}$-yellow, and $\{10 \overline{2}\}$-red. The $\{010\}$-purple pinacoid limits the pseudo prismatic development [31]. (b) Experimental growth shape in pure aqueous solution. (c) Experimental growth shape in the presence of citrate: a part of the platy aspect, a new $\{10 \overline{1}\}$-green appears and, according to Figure 2, the elongated HAp platelets do nucleate successively, giving rise to complex arrangements, welded either on the $\{10 \overline{1}\}$ or $\{001\}$ faces (or both, (or both, as drawn in Figure SI4), rerepresented in (d,e).

\section{Conclusions}

The interaction between Ca-hydroxyapatite growing from aqueous solution and the ion citrate used as additive once more shows that only the monoclinic $\left(P 2_{1} / c\right)$ HAp polymorph can crystallize 
below $135^{\circ} \mathrm{C}$. Starting from the consideration that, under this thermodynamic condition, citrate ions can form only one stable 3D-ordered phase (i.e., the triclinic Ca-citrate-tetrahydrate), we produced HAp crystals from aqueous solutions that are initially supersaturated with respect to HAp, but unsaturated with respect to Ca-citrate-tetrahydrate. The change of morphology and habit undergone by HAp is dramatic: when going from pure aqueous solution (or citrate-doped, but at crystallization temperatures higher than $135^{\circ} \mathrm{C}$ ) to citrate-doped solutions, HAp crystals become strongly [010] elongated and $\{001\}$ platy. The usual pseudo-hexagonal rod-shaped crystals disappear and new fence-like aggregates take place. In turn, these aggregates can be divided in two types: in the first ones, individual HAp single crystals successively nucleate side-by-side, being welded through their $\{10 \overline{1}\}$ faces; in the other ones, they nucleate piled on top of each other but welding occurs through their $\{001\}$ faces.

All these changes are interpreted in the light of epitaxial adsorption, on HAp surfaces, of 2D islands of Ca-Cit-TH; epitaxies are supposed to occur on the basis of 2D-coincidence lattices found between the different HAp forms: $\{001\},\{100\},\{10 \overline{2}\},\{010\}$, and $\{10 \overline{1}\}$ and the flat $\{001\}$ form of $\mathrm{Ca}-\mathrm{Cit}-\mathrm{TH}$. The theoretical ground, explaining why Ca-Cit-TH epitaxies can set up at unsaturation, arises from our recent findings and on a historical paper by Kern et al. [37]. Concerning a highlighting point of view on the relationships between coincidence lattices and epitaxy, the readers are kindly invited to consult two papers by Hillier and Ward [38] and Hooks et al. [39].

The selective adsorption of Ca-Cit-TH enhances the morphological importance of the $\{001\}_{\text {HAp }}$ pinacoid, at the expenses of the three other pinacoids: $\{100\},\{10 \overline{2}\}$, and $\{010\}$; moreover, the $10 \overline{1}_{\text {HAp }}$ interface assumes, for the first time, the role necessary to allow the lateral stacking in the fence-like aggregates. Finally, Ca-Cit-TH plays a double role: it works as a strong HAp habit modifier and, at the same time, exerts the function of "mortar" by favouring the assembling of the HAp lamellar "bricks" in two different kinds of aggregates.

New experiments are planned to deepen the knowledge of these findings and to quantitatively evaluate the adhesion energies involved in the related epitaxial relationships.

Supplementary Materials: The following are available online at http:/ /www.mdpi.com/2073-4352/8/8/308/s1, The method used to build a crystal growth model. Figure SI1: (a) the (001) cell of HAp and (b) the (001) cell of Ca-Cit-TH. Figure SI2: 2D coincidence cell between the (001) cell of HAp and the (001) cell of Ca-Cit-TH as reported in Figure SI1. Figure SI3: A new 2D-coincidence cell obtained by rotating the [100 $]_{\mathrm{Ca}-\mathrm{Cit}-\mathrm{TH}}$ vector clockwise by $25^{\circ}$ with respect to the $[100]_{\text {HAp }}$ vector, while the common origin is maintained. Figure SI4: Double fence-like aggregate of Hap crystals welded on both the $\{10 \overline{1}\}$ and the $\{001\}$ faces and their reciprocal arrangement sketched in the scheme.

Author Contributions: Investigation, Methodology, Validation, L.P.; Conceptualization, Writing-Review \& Editing, M.B., L.P. and D.A.; Formal Analysis D.A.

Funding: This research received no external funding.

Conflicts of Interest: The authors declare no conflict of interest.

\section{References}

1. Dickens, F. The citric acid content of animal tissues, with reference to its occurrence in bone and tumour. Biochem. J. 1941, 35, 1011-1023. [CrossRef] [PubMed]

2. Costello, L.C.; Chellaiah, M.; Zou, J.; Franklin, R.B.; Reynolds, M.A. The status of citrate in the hydroxyapatite/collagen complex of bone and its role in bone formation. J. Regener. Med. Tissue Eng. 2014, 3, 4. [CrossRef] [PubMed]

3. Filgueiras, M.R.T.; Mkhonto, D.; de Leeuw, N.H. Computer simulations of the adsorption of citric acid at hydroxyapatite surfaces. J. Cryst. Growth 2006, 294, 60-68. [CrossRef]

4. De Leeuw, N.H.; Rabone, J.A.L. Molecular dynamics simulations surfaces of the interaction of citric acid with the hydroxyapatite (00.1) and (01.0) surfaces in an aqueous environment. CrystEngComm 2007, 9, 1178-1186. [CrossRef]

5. Jiang, W.G.; Chu, X.; Wang, B.; Pan, H.; Xu, X.; Tang, R. Biomimetically triggered inorganic crystal transformation by biomolecules: A new understanding of biomineralization. J. Phys. Chem. B 2009, 113, 10838-10844. [CrossRef] [PubMed] 
6. Rhee, S.H.; Tanaka, J. Effect of citric acid on the nucleation of hydroxyapatite in a simulated body fluid. Biomaterials 1999, 20, 2155-2160. [CrossRef]

7. Hu, Y.Y.; Rawal, A.; Schmidt-Rohr, K. Strongly bound citrate stabilizes the apatite nanocrystals in bone. Proc. Natl. Acad. Sci. USA 2010, 107, 22425-22429. [CrossRef] [PubMed]

8. Terpstra, R.A.; Bennema, P.; Hartman, P.; Woensdregt, C.F.; Perdok, W.G.; Senechal, M.L. F-faces of apatite and its morphology: Theory and observation. J. Cryst. Growth 1986, 78, 468-478. [CrossRef]

9. Delgado-López, J.M.; Iafisco, M.; Rodriguez, I.; Tampieri, A.; Prat, M.; Gómez-Morales, J. Crystallization of bioinspired citrate-functionalized nanoapatite with tailored carbonate content. Acta Biomater. 2012, 8, 3491-3499. [CrossRef] [PubMed]

10. Delgado-López, J.M.; Frison, R.; Cervellino, A.; Gómez-Morales, J.; Guagliardi, A. Masciocchi, N. Crystal size, morphology, and growth mechanism in bio-inspired apatite nanocrystals. Adv. Funct. Mater. 2014, 24, 1090-1099. [CrossRef]

11. Iafisco, M.; Ramirez-Rodriguez, G.B.; Sakhno, Y.; Tampieri, A.; Martra, G.; Gómez-Morales, J.; Delgado-López, J.M. The growth mechanism of apatite nanocrystals assisted by citrate: Relevance to bone mineralization. CrystEngComm 2015, 17, 507-511. [CrossRef]

12. Martínez-Casado, F.J.; Iafisco, M.; Delgado-López, J.M.; Martínez-Benito, C.; Ruiz-Pérez, C.; Colangelo, D.; Oltolina, F.; Prat, M.; Gómez-Morales, J. Bioinspired citrate-apatite nanocrystals doped with divalent transition metal ions. Cryst. Growth Des. 2016, 16, 145-153. [CrossRef]

13. Li, M.; Wang, L.; Zhang, W.; Putnis, C.V.; Putnis, A. Direct observation of spiral growth, particle attachment, and morphology evolution of hydroxyapatite. Cryst. Growth Des. 2016, 16, 4509-4518. [CrossRef]

14. Sato, K.; Kogure, T.; Kumagai, Y.; Tanaka, J. Crystal orientation of hydroxyapatite induced by ordered carboxyl groups. J. Colloid Interface Sci. 2001, 240, 133-138. [CrossRef] [PubMed]

15. Hu, Y.Y.; Liu, X.P.; Ma, X.; Rawal, A.; Prozorov, T.; Akinc, M.; Mallapragada, S.K.; Schmidt-Rohr, K. Biomimetic self-assembling copolymer-hydroxyapatite nanocomposites with the nanocrystal size controlled by citrate. Chem. Mater. 2011, 23, 2481-2490. [CrossRef]

16. Davies, E.; Müller, K.H.; Wong, W.C.; Pickard, C.J.; Reid, D.G.; Skepper, J.N.; Duer, M.J. Citrate bridges between mineral platelets in bone. Proc. Natl. Acad. Sci. USA 2014, 111, E1354-E1363. [CrossRef] [PubMed]

17. Delgado-López, J.M.; Bertolotti, F.; Lyngsø, J.; Skov Pedersen, J.S.; Cervellino, A.; Masciocchi, N.; Guagliardi, A. The synergic role of collagen and citrate in stabilizing amorphous calcium phosphate precursors with platy morphology. Acta Biomater. 2017, 49, 555-562. [CrossRef] [PubMed]

18. Wang, X.; Zhang, L.; Liu, Z.; Zeng, Q.; Jiang, G.; Yang, M. Probing the surface structure of hydroxyapatite through its interaction with hydroxyl: A first principle study. RSC Adv. 2018, 8, 3716-3722. [CrossRef]

19. Gómez-Morales, J. An overview of the role of the organic matrix in the formation of biogenic crystals. In Proceedings of the 6th International School of Crystallization, Granada, Spain, 21-25 May 2018.

20. Aquilano, D.; Bruno, M.; Rubbo, M.; Pastero, L.; Massaro, F.R. Twin laws and energy in monoclinic hydroxyapatite, $\mathrm{Ca}_{5}\left(\mathrm{PO}_{4}\right)_{3}(\mathrm{OH})$. Cryst. Growth Des. 2015, 15, 411-418. [CrossRef]

21. Pastero, L.; Aquilano, D. Monetite-assisted growth of micrometric Ca-hydroxyapatite crystals from mild hydrothermal conditions. Cryst. Growth Des. 2016, 16, 852-860. [CrossRef]

22. Pastero, L.; Bruno, M.; Rubbo, M.; Cámara, F.; Aquilano, D. Growth of large ca-hydroxyapatite crystals from aqueous solution. In Proceedings of the IV Meeting of the Italian and Spanish Crystallographic Associations, IV MISCA, Puerto de la Cruz, Spain, 21-25 June 2016; p. 27.

23. Barbooti, M.M.; Al-Sammerrai, D.A. Thermal decomposition of citric acid. Thermochim. Acta 1986, 98, 119-126. [CrossRef]

24. Wang, L.M.; Wang, W.; Li, X.C.; Peng, L.; Lin, Z.Q.; Xu, H.Z. Calcium citrate: A new biomaterial that can enhance bone formation in situ. Asian Pac. J. Trop. Med. 2012, 15, 291-296.

25. Pastero, L.; Costa, E.; Bruno, M.; Rubbo, M.; Sgualdino, G. Aquilano, D. Morphology of calcite $\left(\mathrm{CaCO}_{3}\right)$ growing from aqueous solutions in the presence of $\mathrm{Li}^{+}$ions. Surface behaviour of the $\{0001\}$ form. Cryst. Growth Des. 2004, 4, 485-490. [CrossRef]

26. Pastero, L.; Aquilano, D.; Costa, E.; Rubbo, M. 2D epitaxy of lithium carbonate inducing growth mechanism transitions on $\{0001\}-\mathrm{K}$ and $\{018\}-\mathrm{S}$ forms of calcite crystals. J. Cryst. Growth 2005, 275, e1625-e1630. [CrossRef]

27. Pastero, L.; Aquilano, D. $\mathrm{CaCO}_{3}$ (calcite) $/ \mathrm{Li}_{2} \mathrm{CO}_{3}$ (zabuyelite) anomalous mixed crystals. Sector zoning and growth mechanisms. Cryst. Growth Des. 2008, 8, 3451-3460. [CrossRef] 
28. Pastero, L.; Aquilano, D.; Moret, M. Selective adsorption/absorption of formamide in $\mathrm{NaCl}$ crystals growing from solution. Cryst. Growth Des. 2012, 12, 2306-2314. [CrossRef]

29. Pastero, L.; Cossio, R.; Aquilano, D. $\{100\} \rightarrow\{111\}$ morphological change on $\mathrm{KCl}$ crystals grown from $\mathrm{Pb}^{2+}$ doped aqueous solutions. CrystEngComm 2015, 17, 7844-7855. [CrossRef]

30. Pastero, L.; Aquilano, D. A three-modal epitaxial adsorption of formamide $\left(\mathrm{HO}-\mathrm{C}-\mathrm{NH}_{2}\right)$ on the $\{111\}$ surfaces of f.c.c. alkali halides crystals growing from aqueous solution. CrystEngComm 2016, 18, 9067-9076. [CrossRef]

31. Aquilano, D.; Bruno, M.; Rubbo, M.; Massaro, F.R.; Pastero, L. Low symmetry polymorph of hydroxyapatite. Theoretical equilibrium morphology of the monoclinic $\mathrm{Ca}_{5}(\mathrm{OH})\left(\mathrm{PO}_{4}\right)_{3}$. Cryst. Growth Des. 2014, 14, 2846-2852. [CrossRef]

32. Herdtweck, E.; Kornprobst, T.; Sieber, R.; Straver, L.; Plank, J. Crystal structure, synthesis, and properties of tri-calcium di-citrate tetra-hydrate $\left[\mathrm{Ca}_{3}\left(\mathrm{C}_{6} \mathrm{H}_{5} \mathrm{O}_{7}\right)_{2}\left(\mathrm{H}_{2} \mathrm{O}\right)_{2}\right] \cdot 2 \mathrm{H}_{2} \mathrm{O}$. Z. Anorg. Allg. Chem. 2011, 637, 655-659. [CrossRef]

33. Bruno, M.; Massaro, F.R.; Rubbo, M.; Prencipe, M.; Aquilano, D. (10.4), (01.8), (01.2), and (00.1) twin laws of calcite $\left(\mathrm{CaCO}_{3}\right)$ : Equilibrium geometry of the twin boundary interfaces and twinning energy. Cryst. Growth Des. 2010, 10, 3102-3109. [CrossRef]

34. Aquilano, D. Complex growth polytypism and periodic polysynthetic twins on octacosane crystals (n-C28H58). J. Cryst. Growth 1977, 37, 215-228. [CrossRef]

35. Boistelle, R.; Aquilano, D. Interaction energy and growth mechanisms on twinned and polytypic crystals of long-chain even normal-alkanes. I. Interaction-energy calculations. Acta Crystallogr. A 1977, 33, 642-648. [CrossRef]

36. Pastero, L.; Aquilano, D. Calcium carbonate polymorphs growing in the presence of sericin: A new composite mimicking the hierarchic structure of nacre. Crystals 2018, 8, 263. [CrossRef]

37. Kern, R.; Le Lay, G.; Métois, J.J. Basic mechanisms in the early stages of epitaxy. In Current Topics in Materials Science; Kaldis, E., Ed.; North-Holland Publishing Company: Amsterdam, The Netherlands, 1979; Volume 3, pp. 131-419.

38. Hillier, A.C.; Ward, M.D. Epitaxial interactions between molecular over-layers and ordered substrates. Phys. Rev. B 1996, 54, 14037-14051. [CrossRef]

39. Hooks, D.E.; Fritz, T.; Ward, M.D. Epitaxy and molecular organization on solid substrates. Adv. Mater. 2001, 13, 227-241. [CrossRef] 